\title{
Chromophoric and liability quantification of organic matters in the polluted rivers of Bandung watershed, Indonesia
}

\author{
Mohamad Rangga Sururi*, Dwina Roosmini, and Suprihanto Notodarmojo \\ Institut Teknologi Bandung, Environmental Engineering Department, Ganesha 10 Bandung, Indonesia
}

\begin{abstract}
The environmental pressure on raw water intakes has increased and affected the characteristic of Natural Organic Matters (NOMs) in many rivers in Indonesia. The purpose of this study is to determine the characteristic of NOMs and to understand the relationship among NOMs parameters in the polluted river intakes. This research was conducted in the raw water intakes of Water Supply Company in Bandung Indonesia. Statistical and spatial analysis were applied to obtain the most polluted water among the intakes. Then, water samplings from a selected intake were taken to measure three different terminologies of NOMs, which are (i) NOM which are related to lability (BOD and COD), (ii) Chromophoric NOM (UV 254, UV 355 , and UV $3 / 4$ ), (iii) and fluorescent NOM (Humification Index (HIX)). In this study, the Fluorescent ExcitationEmission Matrix (F-EEM) was then measured to determine the origins of NOMs. Also, further results reveal that the characteristic of NOMs from the selected water intake is predominantly influenced by anthropogenic activities, as shown by weak relationship among lability NOM and Chromophoric NOM.
\end{abstract}

\section{Introduction}

The presence of Natural Organic Matter (NOM) is an important parameter to describe the quality of raw water. The problem related to NOM became a crucial since the anthropogenic activities give the pressure to the rivers as the water sources of Water Company. Human activities along the watershed have degraded the quality of water, thus it is important to determine the effects of land use on the organic composition in the river watershed [1].

The NOM composition in the raw water can be different among the watersheds due to the dissimilar of land use patterns [2]. Moreover, NOM characteristic can be affected by a variety of environmental factors, such as the geomorphology, hydrology, aquatic light intensity and microbial activity within the watershed $[2,3]$.

According to Yamashita, Maie, Briceño and Jaffé [3], the biogeochemistry of Dissolved Organic Matter (DOM) in typical tropical rivers, such as Indonesia, might be quite sensitive to climatic and land use change. The problems related to liability of NOM had enforced the challenges to the water treatment facilities in terms of operational optimization and proper process control [4, 5]. An additional problem related to NOM arose due to wide use of chlorination in water treatment plant. NOM that does not remove by the treatment process reacts with chlor to form Disinfection by Products (DBPs), such as Trihalomethanes (THMs).

$\mathrm{NOM}$ in the water is very heterogeneous, and consists of complex mixture. Different terminologies and parameters have been used to describe it in the water [6, 7]. Inappropriate measurements of NOM will lead to ambiguous perception.
In developing countries such as Indonesia, the organic content in the drinking raw water is measured as Biochemical Oxygen Demand (BOD) and Chemical Oxygen Demand (COD). Both acronyms were used in the study related NOM when the labiality criteria are involved [6]. BOD and COD worked in the best on waste-water effluents and they had the widest application in measuring wastes from the treatment plants [8]. Nevertheless, there are no strong relationship among BOD,COD and THMs $[9,10]$. Meanwhile, some experts have concluded that Dissolved organic carbon, Chromophoric NOM (CNOM), SUVA (Specific Ultraviolet Absorbance) correlated with THMs, thus it served as surrogate parameter for THMs [11-16].

In Indonesia, one of the greatest challenges is the limited information regarding the characteristic and quantity CNOM (UV254, UV 355 and UV3/4); and fluorescent NOM (HIX); at raw water sources. Both terminologies are important surrogate parameter of THMs forming potential in the raw water.

The objective of this study was to determine the characteristic of NOM and understanding relationship among NOM parameters on the polluted raw water. This study also determines the origin of NOM by the fluorescent excitationemission matrix (F-EEM).

\footnotetext{
*Corresponding author: rangsoer@gmail.com
} 


\section{Material and Methods}

\subsection{The study area}

Bandung is the capital of West Java Province in Indonesia. The water company who supplies drinking water for Bandung City is PDAM Tirtawening. They had generated the drinking water of $1,904.86 \mathrm{~L} / \mathrm{sec}$ from surface water and less than $115 \mathrm{~L} / \mathrm{sec}$ from others sources. In Water production region 2, there are three main rivers, providing raw water for treatment plant. These rivers are Cikapundung; Cipanjalu and Cibeureum, which part of the Citarum Catchment [17].

The study area is shown in Figure 1. The PDAM Tirtawening has measured BOD and COD every 3 months in period of 2013-2016. The data were analysed statistically by ANOVA using SPSS 19 to determine the most polluted intake which would be sampling location. In order to strengthen the statistic results, land use analysis was used to determine the natural area and anthropogenic areas which were affected by human activities in the catchment area of four intakes.

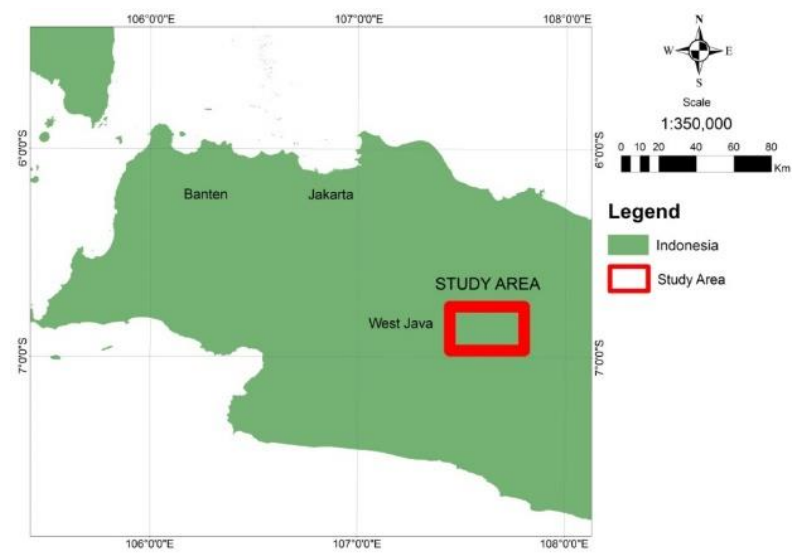

Fig.1. Study area

\subsection{Water sample collection}

The sampling on selected intake location was conducted on 9 days of measurements. The sampling was taken after first sedimentation before coagulation processes thus the composition of DOC has not changed.

\subsection{NOM measurements}

Table 1 shows, the list of NOM parameters which were measured and the standard of measurement. Spectrophotometer UV-VIS CAMSPEC M500 series was used to measure COC. $\mathrm{UV}_{355}$ is describes the CDOM derived from terrestrial [18]. Comparison of UV300 and UV400, describes the humification in the sample, the lower of ratio, the higher humification and aromatization [19].

Spectrophotometer fluorescence Shimadzu RF5301PC was used to measure HIX, the ratio $\mathrm{H} / \mathrm{L}$, where $\mathrm{H}$ is the fluorescence intensity recorded at excitation wavelength $254 \mathrm{~nm}$ for emission spectrum integrated from 435 to $480 \mathrm{~nm}$, and $\mathrm{L}$ the fluorescence intensity recorded at excitation wavelength $254 \mathrm{~nm}$ for emission spectrum integrated from 300 to 345 $\mathrm{nm}[20,21]$. The greater value of HIX, the higher value of aromatization $[20,21]$.

Table 1. Method of measurements

\begin{tabular}{|c|c|c|}
\hline No & Parameter & Measurement method \\
\hline 1 & BOD & Standard methods 5210 B \\
\hline 2 & COD & Standard methods 5220 C \\
\hline 3 & DOC & Standard methods 3510 B \\
\hline 4 & UV $_{254}$ & Standard methods 3510 B \\
\hline
\end{tabular}

\subsection{Correlation among NOM parameters}

In this research, a correlation is a single number that describes the relationship between NOM parameters. The data were 2 nalysed statistically by SPSS 19.

\subsection{The sources of NOM determination}

NOM from watershed which are affected by human activities dominated by protein like and others which are affected by natural activities dominated by humic like [1]. In this part of research, the samples were divided to filtered and unfiltered sample. The samples were filtered by Advantech membrane with diameter of $0.45 \mathrm{~m} \mu$ to know dissolved organic sources.

Spectrophotometer fluorescence Shimadzu RF5301PC was used to measure fluorescent excitation-emission matrix (F-EEM). Table 2 Shows the F-EEM of fluorescence intensity peaks selected based on the F-EEMs contour plots. The maximum intensities of the two humic-like peaks are much higher than of the protein-like peaks.

Table 2. F-EEM of fluorescence intensity peaks

\begin{tabular}{|c|c|c|c|l|}
\hline \multicolumn{2}{|c|}{ Excitation, nm } & \multicolumn{2}{c|}{ Emission, nm } & \multirow{2}{*}{ Fluorophore } \\
\cline { 1 - 4 } (Coble, & $\begin{array}{c}\text { (Baghoth } \\
\text { 2012) }\end{array}$ & $\begin{array}{c}\text { (Coble, } \\
\text { 1996) }\end{array}$ & $\begin{array}{c}\text { (Baghoth } \\
\text {, 2012) }\end{array}$ & \\
\hline 275 & 280 & 310 & 320 & $\begin{array}{l}\text { Tyrosine, } \\
\text { protein like }\end{array}$ \\
\hline 275 & 280 & 340 & 350 & $\begin{array}{l}\text { Tryptophan, } \\
\text { protein-like }\end{array}$ \\
\hline 350 & 330 & $\begin{array}{c}420- \\
480\end{array}$ & 450 & Humic like \\
\hline 312 & 310 & $\begin{array}{c}380- \\
420\end{array}$ & 410 & $\begin{array}{l}\text { Humic, } \\
\text { marine } \\
\text { humic }\end{array}$ \\
\hline
\end{tabular}

\section{Result and discussion}

\subsection{Location determination}

The most polluted water sample was determined by using series BOD and COD data from PDAM Tirtawening. The measurement result for BOD 
during period 2013-2016 can be seen at Figure 2, meanwhile COD can be seen at Figure 3.

Figures 2-3 show, during period of sample, BOD and COD concentration were fluctuated at every sampling point. The highest BOD and COD concentration were recorded at Bantar Awi intake with concentration of 85 $\mathrm{mg} / \mathrm{L}$ and $262,78 \mathrm{mg} / \mathrm{L}$ respectively. These values are far above Indonesia stream standard for both parameters which are $2 \mathrm{mg} / \mathrm{L}$ and $10 \mathrm{mg} / \mathrm{L}$ for BOD and COD, respectively.

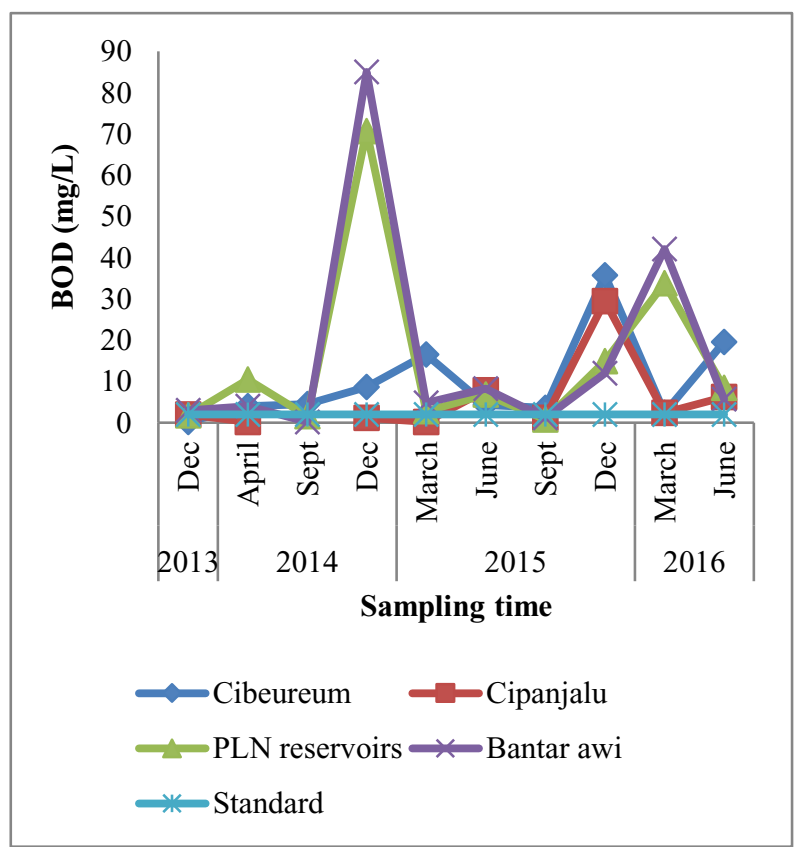

Fig.2. BOD concentration at intake between 2013-2016 (source: PDAM Tirtawening,2017)

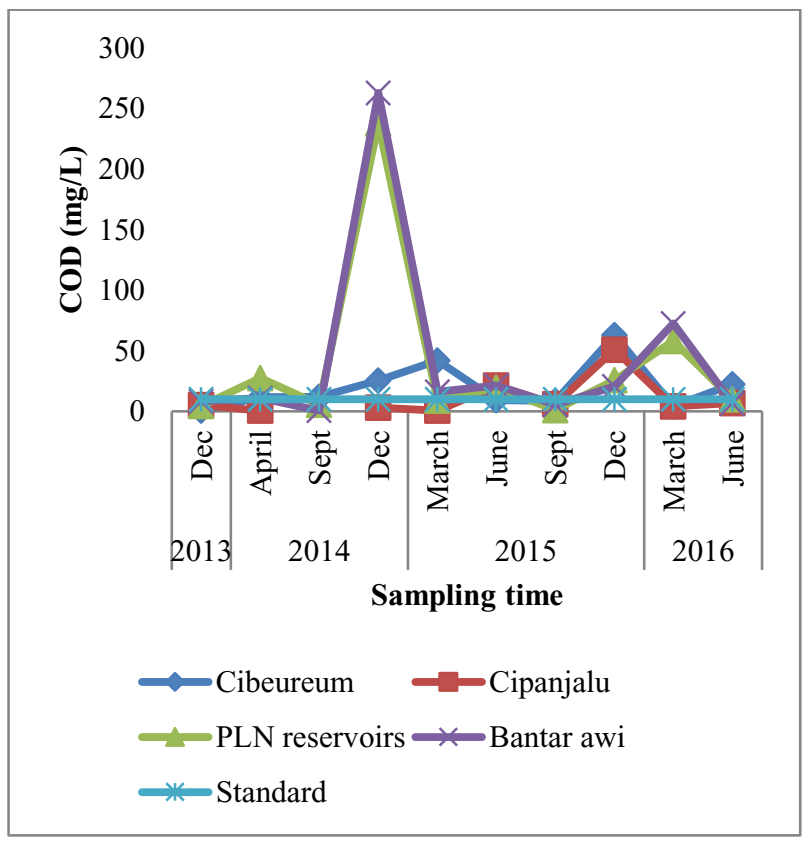

Fig.3. COD concentration at intake between 2013-2016 (source: PDAM Tirtawening,2017)

SPSS 19 was used for Homogeneities and Anova test. Homogeneities test results shows significant values for both parameters were 0.097 ; these were higher than the sig, so that Ho was accepted, and it means that the variance of BOD and COD on all four sources are homogen. Anova test result was showed there were no significant differences of mean value between all four sources, these were because the concentration of BOD and COD at every sampling points commonly exceed than standards. However, BOD and COD concentration at Bantar Awi intake have recorded the worst among the intake.

Figure 4 shows the catchment area all of intakes, although there were several type of land use, due to research purposes, these were grouped into two grouped namely:

1. Natural area (green), there were no significant human activities in this area,

2. Developed area (yellow), there were significant human activities in these area.

Figure 4 shows, the two largest developed area were found in Bantar Awi and PLN Reservoir, but at PLN reservoir intake, the water had been stored at the particular time at reservoir, so the qualities of the water at the intake was better compare to Bantar Awi intake.

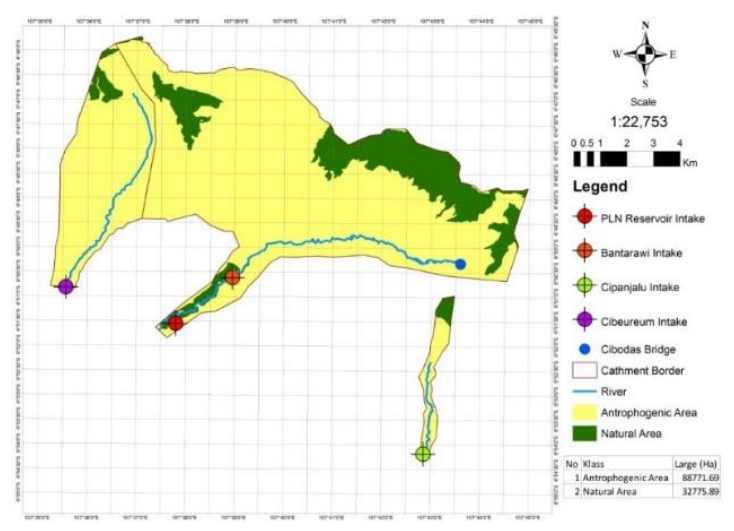

Fig.4. Land use pattern in catchment area of the intake

According statistical and spatial analysis, the worst organic concentration at raw water found in Bantar Awi intake. These intakes provide \pm 600 $\mathrm{L} / \mathrm{sec}$ of raw water for Dago Pakar treatment plant.

\subsection{NOM measurements}

Table 3 shows the organic characteristic of the sample and Table 4 shows the correlation among organic parameters. Table 3 shows, the measurement result $\mathrm{BOD} / \mathrm{COD}$ of the samples were between $0.17-0.46$. These values indicated that nonbiodegradable organic parts were far higher than biodegradable organic part. BOD of the sample was between $1.5 \mathrm{mg} / \mathrm{L}-13.2 \mathrm{mg} / \mathrm{L}$ and COD of the sample around $5 \mathrm{mg} / \mathrm{L}-57.6 \mathrm{mg} / \mathrm{L}$. Table 4 shows; there was strong correlation between BOD and COD (sig 0.05 and p 0.05). However, it was found the relationships of both parameters with BOD/COD were weak. 
Table 3 Organic characteristic

\begin{tabular}{|c|cccc|}
\hline Parameters & \multicolumn{4}{|c|}{ Value } \\
\hline BOD & 1.5 & - & 13.2 & $\mathrm{mg} / \mathrm{L}$ \\
\hline $\mathrm{COD}$ & 5 & - & 57.6 & $\mathrm{mg} / \mathrm{L}$ \\
\hline $\mathrm{BOD} / \mathrm{COD}$ & 0.17 & - & 0.46 & - \\
\hline $\mathrm{UV}_{254}$ & 0.189 & - & 0.596 & $(\mathrm{~cm}-1)$ \\
\hline $\mathrm{UV}_{355}$ & 0.076 & - & 0.447 & $(\mathrm{~cm}-1)$ \\
\hline $\mathrm{A} 3 / \mathrm{A} 4$ & 1.49 & - & 2.65 & - \\
\hline $\mathrm{HIX}$ & 0.71 & - & 1.79 & - \\
\hline
\end{tabular}

Organic aromatic as $\mathrm{UV}_{254}$ were between $0.189 \mathrm{~cm}^{-1}$ and $0.596 \mathrm{~cm}^{-1}$. Hua, Reckhow and Abusallout [22] reported that the $\mathrm{UVA}_{254}$ value at three intakes in USA, wherein the values were between $0,114 \mathrm{~cm}^{-1}$ and 0,313 $\mathrm{cm}^{-1}$. That study also reported that the highest value of $\mathrm{UV}_{254}$ recorded at the watershed of the Assomption River, was highly influenced by agricultural activities. The $\mathrm{UV}_{254}$ values of Bantar Awi intake were higher than that of Assomption River because it was influenced by heterogeneous activities around the catchment.

$\mathrm{UV}_{355}$ is used to determine organic aromatic from terrestrial (allochthonous NOM) [19]. The $\mathrm{UV}_{355}$ values were between $0.076 \mathrm{~cm}^{-1}$ and 0.447 $\mathrm{cm}^{-1}$, these were lower than that of $\mathrm{UV}_{254}$. This condition happened as in the water sample, there were others aromatic sources besides from terrestrial. These aromatic sources might from others allochthonus NOM or from secondary NOM (autochthonous NOM). However, based on the values of UV 254 and $U_{355}$, organic aromatic in the water sample $60 \%$ (average) were from terrestrial, and these values were higher, compared to $U_{355}$ at Yangtze estuary in China, where the effect of dilution is significant [23]. This finding shows that the allochthonus sources contributed significantly to organic aromatic composition in the water sample. This phenomenon was strengthen by strong correlation between $\mathrm{UV}_{355}$ and $\mathrm{UV}_{254}$ ( $\operatorname{sig} 0,01$ ) (Table 3).

Table 4. Correlation among BOD,COD and CTOC

\begin{tabular}{|c|c|c|c|c|c|c|c|c|}
\hline & & BOD & COD & $\mathbf{U V}_{254}$ & A3/4 & HIX & BOD/COD & $\mathbf{U V}_{355}$ \\
\hline BOD & $\begin{array}{l}\text { Pearson Correlation } \\
\text { Sig. (2-tailed) }\end{array}$ & 1 & \multirow[b]{2}{*}{1} & & & & & \\
\hline $\mathrm{COD}$ & $\begin{array}{l}\text { Pearson Correlation } \\
\text { Sig. (2-tailed) }\end{array}$ & $\begin{array}{l}.736^{*} \\
.024\end{array}$ & & & & & & \\
\hline $\mathrm{UV}_{254}$ & $\begin{array}{l}\text { Pearson Correlation } \\
\text { Sig. (2-tailed) }\end{array}$ & $\begin{array}{l}-.478 \\
.193\end{array}$ & $\begin{array}{l}-.304 \\
.427\end{array}$ & 1 & & & & \\
\hline $\mathrm{A} 3 / \mathrm{A} 4$ & $\begin{array}{l}\text { Pearson Correlation } \\
\text { Sig. (2-tailed) }\end{array}$ & $\begin{array}{c}-.016 \\
.968\end{array}$ & $\begin{array}{l}.325 \\
.394\end{array}$ & $\begin{array}{l}-.546 \\
.128\end{array}$ & 1 & & & \\
\hline HIX & $\begin{array}{l}\text { Pearson Correlation } \\
\text { Sig. (2-tailed) }\end{array}$ & $\begin{array}{l}.209 \\
.590\end{array}$ & $\begin{array}{l}.064 \\
.870\end{array}$ & $\begin{array}{l}-.400 \\
.286\end{array}$ & $\begin{array}{l}.167 \\
.667\end{array}$ & 1 & & \\
\hline $\mathrm{BOD} / \mathrm{COD}$ & $\begin{array}{l}\text { Pearson Correlation } \\
\text { Sig. (2-tailed) }\end{array}$ & $\begin{array}{l}.464 \\
.208\end{array}$ & $\begin{array}{l}-.243 \\
.529\end{array}$ & $\begin{array}{c}-.329 \\
.387\end{array}$ & $\begin{array}{l}-.462 \\
.211\end{array}$ & $\begin{array}{l}.130 \\
.738\end{array}$ & 1 & \\
\hline $\mathrm{UV}_{355}$ & $\begin{array}{l}\text { Pearson Correlation } \\
\text { Sig. (2-tailed) }\end{array}$ & $\begin{array}{l}-318 \\
.404\end{array}$ & $\begin{array}{l}-.339 \\
.372\end{array}$ & $\begin{array}{l}.922^{* *} \\
.000\end{array}$ & $\begin{array}{l}-.750^{*} \\
.020\end{array}$ & $\begin{array}{l}-.257 \\
.504\end{array}$ & $\begin{aligned}-.033 \\
.933\end{aligned}$ & 1 \\
\hline
\end{tabular}

* Correlation is significant at the 0.05 level (2-tailed).

** Correlation is significant at the 0.01 level (2-tailed).

A 3/4 describes the humification in the sample. Table 3 noted, the ratios were between 1.49-2.19. These showed that all the samples values were less than 5 , and these indicated that the sample were dominated by humic acid material, compared to fulfic acid. Meanwhile, humification can be also related to an increase in aromatic character [24]. With regard these two terms, it was found that there was a negative correlation between A3/4 and $\mathrm{UV}_{254}$ although it was not significant. Another term of humic can be explained by the composition and structure of humic depending on its sources. The structure made humic is categorized as Refractory Organic Substance (ROS) [25]. Thus, this why is, in this study, the ratio of BOD/COD ratio were low. Further result shows that ROS can increase not only due to the waste water effluent as discussed in Frimmel [26], but also due to direct discharge of anthropogenic activities as found during the sampling period of this study.
Table 3 also presents that there is no a significant correlation between COD and $\mathrm{UV}_{254}$. According to Mrkva [27], a strong correlation between COD and $\mathrm{UV}_{254}$ on polluted water was resulted in lignin contamination, wherein lignin can be impurities from nature. Furthermore, Zhang, Yin, Feng, Zhu, Shi, Liu and Zhang [28] also found that a strong correlation between the two parameters can occur mainly on humic-dominated samples. While, there was low correlation between the two parameters if the samples were derived from protein [29]. From this information, it is expected that the sample in this study was dominated by protein which will be discussed in final section of this paper.

The FDOM value was represented by HIX as presented in Table 3. The HIX of sample were 1,1-1,39. HIX values were $<4$ corresponding to biological material $[20,21]$. In contrast, the value of $\mathrm{BOD} / \mathrm{COD}$ was dominated by non-biodegradable organic as presented in Table 3. The HIX value also shows different 
interpretation with A3/4 showing the sample was dominated by humic material, and there was negative correlation between HIX and UV 355 and $\mathrm{UV}_{254}$ (Table 4). This strengthen Chen, Zheng, Song and Qin [24]'s finding which reported that ultraviolet-visible absorption is negatively correlated with HIX.

\subsection{The source of the NOM}

The characteristic of the NOM is dominated by protein, as shown in Table 5 discussing the F-EEM of fluorescence intensity by single peaks using excitation's wavelength of $280 \mathrm{~nm}$. It was found that the peak of emission was between $311 \mathrm{~nm}$ and $349 \mathrm{~nm}$. These confirmed that the samples were dominated by protein-like humic both tyrosine-like and tryptophan-like. The land use around the catchment was dominated by built area such as traditional market, residential area, farms and agricultural. Yang, Hong, Guo, Huang, Li and $\mathrm{Yu}$ [1] discussed that protein like fluorophore dominated at watershed areas which are affected by human activities such as residential area.

Table 5. F-EEM of fluorescence intensity peaks of sample

\begin{tabular}{ccc}
\hline Sample & Excitation,nm & Emission,nm \\
\hline D-1 & 280 & 311 \\
D+1 & 280 & 342 \\
D-2 & 280 & 312 \\
D+2 & 280 & 349 \\
D-3 & 280 & 312 \\
D+3 & 280 & 311 \\
D-4 & 280 & 311 \\
D+4 & 280 & 311 \\
D-5 & 280 & 311 \\
D+5 & 280 & 334 \\
\hline
\end{tabular}

\section{Conclusion}

Land use pattern is affected the characteristic of organic matter in the water intakes. It was found significant correlations were found between (i) BOD and COD, (ii) $\mathrm{UV}_{254}$ and $\mathrm{UV}_{355}$ and (iii) $\mathrm{A} 3 / 4$ and $\mathrm{UV}_{355}$, while the relationship between lability NOM and Chromophoric NOM was weak. This results reveal that the characteristic of NOMs from the selected water intake is predominantly influenced by anthropogenic activities which dominantly comprise of protein.

\section{References}

1. L. Yang, H. Hong, W. Guo, J. Huang, Q. Li, and X. $\mathrm{Yu}$, Regional Environmental Change, 12, 145151(2012)

2. C.A.Stedmon and S. Markager, Limnology and Oceanography, 50, 686-697(2005)

3. Y.Yamashita, , N. Maie, H. Briceño, and R. Jaffé, Journal of Geophysical Research, 115, (2010)
4. O Gibert, B. Lefèvre, A. Teuler, X. Bernat, and J. Tobella, Journal of Water Process Engineering, 6, 6471(2015).

5. R.Fabris, , C.W. Chow, M. Drikas, and B. Eikebrokk, Water research,42, 4188-4196 (2008)

6. M.Filella, Environmental chemistry letters, 7, 21-35 (2009)

7. T.Pagano, M. Bida, and J.E. Kenny, Water, 6, 28622897(2014)

8. E.M.Thurman, , Organic geochemistry of natural waters. Vol. 2. Springer Science \& Business Media (1985)

9. M.A.El-Shafy and A. Grünwald, Water Research, 34, 3453-3459 (2000)

10. M.Haddad, L. McNeil, and N. Omar, Arabian Journal for Science and Engineering,39,5883-5893(2014).

11. J.Awad, , J. van Leeuwen, C. Chow, M. Drikas, R.J. Smernik, D.J. Chittleborough, and E. Bestland,. Journal of Hazardous Materials,308, 430-439(2016).

12. D.A.Reckhow, P.C. Singer, and R.L. Malcolm,Environmental science \& technology, 24, 1655-1664(1990).

13. N Ates,., S.S. Kaplan, E. Sahinkaya, M. Kitis, F.B. Dilek, and U. Yetis, Journal of hazardous materials, 142, 526-534(2007)

14. A.D.Pifer and J.L.Fairey,Environmental engineering science, 31, 117-126(2014).

15. D.Ma, B. Peng, Y. Zhang, B. Gao, Y. Wang, Q. Yue, and Q. Li, Bioresource technology, 165, 8187(2014).

16. Z.-Y.Zhao, J.-D. Gu, X.-J. Fan, and H.-B. Li, Journal of hazardous materials, 134, 60-66(2006).

17. I.Juwana, B. Perera, and N. Muttil,"Conceptual framework for the development of West Java water sustainability index". in 18th World IMACS Congress and MODSIM09 International Congress on Modelling and Simulation, 3343-3349(2009)

18. P.G.Dainard, and C. Guéguen, Marine Chemistry, 157, 216-223(2013).

19. R.Artinger, G. Buckau, S. Geyer, P. Fritz, M. Wolf, and J. Kim, Applied Geochemistry, 15, 97-116(2000)

20. C.Guéguen, D.C. Burns, A. McDonald, and B. Ring, Chemosphere, 87, 932-937(2012).

21. A.Huguet, L. Vacher, S. Relexans, S. Saubusse, J.-M. Froidefond, and E. Parlanti, Organic Geochemistry, 40, 706-719(2009).

22. G.Hua, D.A. Reckhow, and I. Abusallout, Chemosphere, 130, 82-89(2015).

23. Y.Wang, , D. Zhang, Z. Shen, J. Chen, and C. Feng, Chemosphere, 95, 353-362(2014).

24. H.Chen, , B. Zheng, Y. Song, and Y. Qin, Aquatic Sciences, 73, 103-112(2011).

25. H.-R.Schulten, B. Plage, and M. Schnitzer, Naturwissenschaften, 78, 311-312(1991).

26. F.H.Frimmel, Biopolymers Online, 1, (2005).

27. M.Mrkva, Water research, 17, 231-235(1983) 
28. Y.Zhang, Y. Yin, L. Feng, G. Zhu, Z. Shi, X. Liu, and Y. Zhang, water research, 45, 5110-5122(2011).

29. J.Zhang, J. Yu, W. An, J. Liu, Y. Wang, Y. Chen, J. Tai, and M. Yang, Journal of Environmental Sciences, 23, 183-188(2011). 